\title{
Body composition changes of multiparous sows during the reproductive cycle Influence of the level of feed intake during lactation
}

\author{
M. ETIENNE, J.P. PICHOT, B. DESMOULIN
}

I.V.R.A., Station de Recherches sur l'Elevage des Porcs, Centre de Rennes-Saint-Gilles, F 35590 L'Hermitage

An experiment was carried out in 50 multiparous sows to determine the nature and importance of the tissues involved in the body composition changes occurring between mating and weaning. They were distributed into 5 groups at 1st post-weaning oestrus, fed $1.8 \mathrm{~kg}$ feed $/ \mathrm{d}(3000 \mathrm{kcal} \mathrm{DE} / \mathrm{kg}$ and $13.5 \mathrm{p} .100 \mathrm{TCP}$ ) during gestation, $3 \mathrm{~kg} / \mathrm{d}$ (group 4) and $6 \mathrm{~kg} / \mathrm{d}$ (group 5) during lactation $(3050 \mathrm{kcal} \mathrm{DE} / \mathrm{kg}$ and $17 \mathrm{p} .100 \mathrm{TCP}$ ) and slaughtered at different stages of the reproductive cycle. At slaughtering, viscera and carcass weights were measured. Fat and muscle thickness were estimated and fat and eye muscle areas were measured on a cross section of the loin. The carcass was thereafter cut and the different cuts weighed. After measurement of its specific gravity a ham was dissected. The dry matter and lipid content of $M$. longissimus dorsi were determined.

During gestation the net weight gain of sows was negative $(-5.6 \mathrm{~kg})$, but this weight loss remained restricted as compared to that observed in non-mated females (group 3 : $-14.5 \mathrm{~kg}$ ). The difference in the weight change between both groups of animals was due to the uterus and mammary gland development, since no difference was observed in the various criteria estimated on the carcass. This indicates that the weight loss during gestation was mainly bound to a fat tissue regression while the muscle mass was not affected. The weight of fat tissues kept on decreasing during lactation, even when sows were fed ad libitum. A decrease in the muscle mass was only observed in females subjected to a severe feed restriction during lactation. Therefore, it seems that in multiparous sows restricted during gestation, the pregnancy anabolism is only limited to the development of the reproductive organs. Moreover, it seems difficult to prevent a reduction in the fat mass of these animals during lactation. Changes in the live weight, even the net weight do not represent good indices of the changes in the body reserves of breeding sows.

\section{Potential prolificacy and winter breeding in free-living wild sows (Sus scrofa scrofa)}

\author{
A. AUMAITRE *, Catherine MORVAN *, J.P. QUERE**, \\ Jany PEINIAU *, G. VALLET ** \\ *I.N.R.A., Station de Recherches sur l'Elevage des Porcs, \\ Centre de Rennes-Saint-Gilles, F 35590 L'Hermitage \\ $\because:$ I.N.R.A., Laboratoire de la Faune sauvage. \\ F 78350 Jouy-en-Josas
}

The genital tracts of wild sows (Sus scrofa scrofa $\mathrm{n}=36$ chromosomes) belonging to two populations living in a closed forest (Parc de Chambord) and in an open forest (Arcen-Barrois), were obtained after a battu in the forests and subjected to a series of observations. 'The data were gathered from 396 pregnant sows examined in Chambord from 1974 to 1981 and from 110 animals in Arc-en-Barrois, between 1977 and 1981. The measurements involved : estimation of mating and farrowing dates, counting and weighing of foetuses and of corpora lutea, weighing of the animal, of the uterus, ovaries, corpora lutea as well as of the foeto-placental annexes.

The main results show the existence of a sexual activity and consequently a breeding season : mating from November to January, farrowing from March to May at Chambord and 
the same activity, but one month earlier at Arc-en-Barrois. Most females exhibited a sexual rest characterized by a regression of genitals and an anoestrus, late summer - early autumn. The breeding season could be more than one month earlier when the oak mast crop was abundant, especially at Chambord (1975-1976 and 1976-1977). As their body development was rather slow, these wild sows living in the forests were pregnant for the first time at the mean age of 18-24 months and at a live weight exceeding $25 \mathrm{~kg}$.

The potential prolificacy estimated from the number of embryos, was low ( $n=4.41$ at Chambord; $n=4.75$ at Arc-en-Barrois). Like in the sow, it varied with the age and weight of the animal. Maximum litter size was reached between 4 and 5 years of age and 2 animals out of 179 carrying 9 foetuses weighed more than $100 \mathrm{~kg}$. The ovulation rate was not very high either (5.05 and 5.5, respectively at Chambord and Arc-en-Barrois and the average embryonic mortality was 13.4 p. 100 . However, this rate varied between a minimum of 12 p. 100 when fall food was abundant and up to 19 p. 100 in years of food scarcity.

Weighing of the ovaries (and of the empty uterus) gives information about the physiological status of the wild sow and allows to clearly distinguish between the infantile phases ( 2 ovaries weighing less than $2 \mathrm{~g}$ ), sexual rest phase (less than $3 \mathrm{~g}$ ), and the cycle followed by gestation $(6-7 \mathrm{~g})$. Weighing of the foetuses allows to describe the mean weight gain in the young $(y)$ by a parabolic equation according to gestation length $(x) Y=236.6-13.02 x$ $+0.176 \mathrm{x}^{2}\left(\mathrm{R}^{\prime \prime}=0.97\right)$. The chemical body analysis of the embryos indicates a dry matter increase with age, a large proportion of proteins and a very low lipid content, as shown in piglet embryos.

The consequences of biological and physiological knowledge about the wild sow, are discussed.

III. - GENETICS

\title{
First results of experiments with chinese pigs in France 1. Reproductive performance in pure and cross breeding with european breeds
}

\author{
C. LEGAULT *, J.C. CARITEZ * \\ I.N.R.A., Station de Génétique quantitative et appliquée, \\ F 78350 Jouy-en-Josas \\ ** I.N.R.A., Domaire expérimental du Magneraud, \\ Saint-Pierre-d'Amilly, F 17700 Surgères
}

The reproductive performance of three native Chinese breeds : Meishan (MS), Jiaxing (JX) and Jinhua $(\mathrm{JH})$ were compared with those of six genetic types of F1 females resulting from the cross of one boar of each Chinese breed with twelve sows of two European breeds : Large White (LW) and French Landrace (LF).

Estimated on a total of 278 purebred and 226 crossbred animals, the average teat number was $16.3 \pm 1.1$ in MS; $19.9 \pm 1.4$ in $\mathrm{JX} ; 16.5 \pm 1.1$ in $\mathrm{JH} ; 14.7 \pm 1.6$ in $\mathrm{F} 1 \mathrm{MS}$; $16.7 \pm 1.7$ in $\mathrm{F} 1 \mathrm{JX}$; and $15.8 \pm 1.4$ in $\mathrm{F} 1 \mathrm{JH}$. On a total of 75 purebred and 114 crossbred gilts, age at puberty was $81 \pm 9 ; 91 \pm 10 ; 109 \pm 15 ; 87 \pm 11 ; 93 \pm 13$ and $96 \pm 14$ days, respectively, for these six genetic types.

Litter size, litter weight and food intake of the sow during the suckling period ( 30 days), were measured on 178 farrowings of which 105 were from gilts.

As far as prolificacy is concerned, we may distinguish between two groups whose litter size at birth and weaning were significantly different. The «prolific» group included four F1 types (MS $\times \mathbf{L F}, \mathbf{M S} \times \mathbf{L W}, \mathrm{JX} \times \mathbf{L F}$ and $\mathrm{JX} \times \mathbf{L W}$ ) and one purebreed (MS). Mean litter size at birth varied from 13.4 to 14.7 and at weaning from 11.4 to 13.3. 